\title{
Understanding the Post-Socialist Experience Across Generations
}

DUŠAN DEÁK

Department of Comparative Religion, Comenius University in Bratislava dusan.deak@uniba.sk

\begin{abstract}
The paper discusses transmission of the historical memories of the comparatively recent past across generations in Slovakia. It introduces the Slovak debate on the recent and difficult pasts, explains the basic theoretical stances, moves on to introduce the regions of the research and the methodology used and finally gives voice to young and older respondents whose information is commented and analyzed. The paper hopes to provide insights into the processes of memory transmission and past construction. As well, by using numerous quotes from the informants, it hopes to illustrate and substantiate the claim about the defects of the debates among the people of current post-socialist era in Slovakia.
\end{abstract}

KEY WORDS: past, intergenerational transmission, historical memory, Slovakia, regime

"Some people had a good life in that era and others did not. Nowadays again, somebody is doing well and the other one not so well. However, life must continue and we have to live."

\section{Introduction}

This paper discusses transmission of the historical memories of the comparatively recent past across generations in Slovakia. It is a partial outcome of the European Commission 
funded research project ${ }^{1}$ that targeted young people and attempted to estimate their vulnerability towards the rising wave of extremist and authoritarian political and social movements. The following lines introduce the Slovak debate on the recent past that, for particular reasons explained below we decided to call as 'difficult', then explain the basic theoretical stances followed, move on to introduce the regions of the research and the methodology used finally to give voice to our young and older respondents whose information is commented and analyzed in passim and at the end of the text. The paper hopes to provide insights into the processes of memory transmission and past construction. As well, by using numerous quotes from the informants, it hopes to illustrate and substantiate the claim about the defects of the debates among the people of current postsocialist era in Slovakia.

There is an ongoing debate in Slovakia on the $20^{\text {th }}$-century regimes of the country and the role that historians play in their evaluation. ${ }^{2}$ This debate has its own history (at least since WWII), its ideological interpretations, as well as its present. The latter can be seen mainly in the current goals of professional historians, who promote their various interpretations of the social, political and economic history of $20^{\text {th }}$-century regimes, and in lay people's alternative interpretations of the past, which operate amidst the remembered and the written pasts. The main points of contention pertain to historical periods, policies and events that still resonate among professionals as well as the common people, e. g., the policies of Czecho-Slovak relations, Hungarian revisionism, the various outcomes of Tiso's regime during the German-satellite Slovak War State (1939-1945), and the forms and practices of the Communist rule (1948-1989). These points of contention contribute to the notion of the 'difficult pasts' ${ }^{3}$. We identified the most problematic themes at the heart of the debate as those related to 1) the idea of "Slovakhood" (mostly czechoslovakism, magyarisation, and, recently, multiculturalism); 2) the level of personal/social freedom and democratic practices during the regimes referred to as authoritarian/totalitarian (the Slovak War State, Communist Czechoslovakia); 3) the criteria by which the knowledge and/or

\footnotetext{
More on the project see at http://www.fp7-myplace.eu/

See more in Historický časopis (2004/2, 2007/1).

By 'difficult past' we understand mainly the periods of social and political unrest that characterized the political regimes described as authoritarian/undemocratic/ totalitarian, or as periods of being 'unfree'. Also, when a society's past is contested, with differing opinions about what that society should learn from the past and how, the competing opinions form the common ground for societal debates on the past, and the agents of these debates take stances on how the past is written down, interpreted, remembered and learnt. This also gives the past the attribute of being 'difficult'. On difficult pasts see more in Deák-Popov (2015).
} 
memory of the critical ("difficult") periods of the Slovak past are assigned value; and 4) the past as politically used/misused capital.

What comes most prominently out of this debate is that whether it takes the form of political collectivity (such as nationhood, a regime, or a democratic society) or of regime ideologies and practices, the past, disputed as it is, has a significant impact on the current political positions of those who engage in the debate, and perhaps even on those who do not. Although to directly associate the effect a particular interpretation of the past has had on concrete political behavior within the current Slovak political streams and their agendas is a complex matter, which is out of the scope of this paper, from our findings ${ }^{4}$ it seems evident that any potential, even if only verbal, articulation of extremist political positions includes recourse to and reasoning with the past. The current debate and its idiom (e.g., the branding of historians or political representatives as Bolshevik, communist, nationalist, fascist, democratic, professional, amateurish, a myth-maker and the like) vividly document how the present is inevitably linked to the past and creates a forum where the followers of extremism may find their place.

Importantly, the discursive factor is formed in the dynamic between the written and the remembered. Living memory (c.f. MAH 2010) based partly on the experiences of the older generation (and to a certain extent also of the younger generation) and set against the written histories and their derivatives provides an alternative, equally necessary, access to the people's pasts. With the help of evidence, it mirrors or challenges the knowledge organized into texts, and, moreover, in using the experience as evidence (see more on this below) it increases the chance that the observer may grasp and interpret how the difficult pasts are produced.

However, it is not only the discursive factor pertaining to history and people's pasts that engages young people's present and forms their political positions. Engagement with the past in terms of practice, active or passive, has also been documented and cannot be avoided if we want to understand what forms youths' attitudes to events long past and the narratives that surround them. What is here taken to be practice is instead a wide array of particular actions that in one or another way bring youth closer to the historical discourses current in Slovakia.

See also a report-paper published on the website of the EU Commission at http://www.fp7myplace.eu/documents/Partner\%204\%20-\%20Slovakia_deliverable_2_1_submission.pdf, accessed 5 September 2015. 
An active reading of a variety of publications on history (professional and lay, printed or electronic, in usual or unusual formats ... etc.) is certainly the most recognizable practice to be taken into consideration. Students, and most of our respondents were indeed students, often not only meet with the past via written texts, but are required to read texts on the past, study them, and, of course, learn from them. Importantly, all of this, with the dominant agency of the state, happens in an organized way. ${ }^{5}$ Thus, familiarity with the organized textual and subsequent discursive knowledge, which is to a considerable extent dominated by the state, is to be expected among this target age group. This does not mean that the textual has no place within the discourses of the older generation and plays no role in the transmission of individual knowledge to succeeding generations. In fact, during our engagement with the families, references to learnt and studied histories were often mentioned (SVKTTR3) ${ }^{6}$, even if they were contextualized with living memories of the past.

Yet, practices related to the engagement of young people with the past do not appear bounded by the discourse, of which the textual discourse seems to be the most significant. Young people, often with the direct assistance of their elders or their school supervisors, may access the past via sites of memory (places that remind one about the past [e.g., the site of a war battle, or of an important or cultural political act], places where the past is deliberately re-enacted, or remembered [e.g. museums, memorials]; c.f. NORA 1989), via locations where the past is addressed, such as meetings, public debates, programs devoted to the past, or even political public gatherings that involve particular interpretations of the past, such as public demonstrations. In all of these, the influence of the older generations is evident and unavoidable, as will be shown later in the paper. Among these practices we may include the current widespread engagement with electronic media, the internet being the most popular among them. Apart from the discursive context of information on the past obtained via electronic media, this form of engagement must be also understood in terms of a practice similar to visits to the sites of memory. Browsing on the internet allows the young consumer observing documentaries with actual images from the past, observing historical speeches, or public representations of historical interpretations and hence observing the past in vivid detail. This practice considerably replaces direct engagement with the sites of memory, and is a practice that contributes to the current knowledge building of young people in many other walks of their lives as well. Even here, though, the

5 An ampt analysis of how the current Slovak state handles the history education can be find in KRATOCHVÍL 2011.

$6 \quad$ SVKTTR3 = Slovakia-Trnava-Respondent 3. Sometimes, when needed, the family position of the respondent is also indicated. If ' $Q$ ' appears after the region location (TT, RS) then the quotation refers to a reply from questionnaire. 
older generation's influence on youths' understanding of the past is not completely avoidable.

Importantly, such practices, then, actively introduce young people to what Basso has called a sense of place (i.e., a sense of historical place in this case, c.f. BASSO 1996), with both Casey (1996) and Malpas (1998) emphasizing its experiential character. Indeed, in many cases, the memory site serves as a place where the past can not only be remembered, but its immanence experienced (c.f. BIRTH 2006). Thus the past-present continuum, i.e., the idea that any past is always addressed from the current present, gets its actual and observable shape - in terms of knowledge, political stance, or active involvement in addressing the past - via a direct experiencing that may lead to other practices such as political/lay activism or passivity.

In fact, the passive, or the refusal to articulate an opinion on the past, is yet another kind of practice. Such a practice could be described as 'presentism'. It is a socio-political standpoint that reflects and measures the lack of interest of our research subjects in getting involved in any form of addressing the past. In the first instance, it stems from a particular and individual lack of interest in the past, and efforts to keep up with the present. When looked at closely, however, this seemingly individual decision is connected to the past in more than one way. People, young or old, don't avoid addressing the past only because of their individual preferences (molded by personal inclinations). They often choose to avoid it because it is too problematic and confusing. This state of affairs has its own historical basis. Since, the ideologization of the past is still taking place in Slovak debates (MICHELA 2008:10-11), people tend to avoid it by avoiding the debated pasts (mostly political and cultural, and rarely individual). Presentism, then, is a socio-political stance, which, to an outside observer, may look like a preference for a passive mode of engagement with the past. However, to a great extent this is a result of a conscious and therefore active choice to avoid further complications in their social lives. The reason for this is the alreadynoted ideologization of the past, and especially the past that we have called 'difficult'. Since any active engagement with it may be socially understood as political action, the activity is avoided and passivity preferred.

Furthermore, there may be economic reasons for presentism. First, there is the financial inability of the people (across generations) to actually visit the sites of memory (see below). If present-day conditions direct people's energies toward making their present and future better, then any, even symbolic, engagement with the difficult pasts is seen as a hindrance and an unnecessary loss of time. Second, if the economic conditions of public institutions are deteriorating, which is often the case in current Slovakia, and if there is little public investment in remembering and re-enacting the past (many memorials are in a dilapidated state, including the greatest WWII memorial in Bratislava, museums are often 
underfinanced, and public commemorative activities are almost at the point of extinction all of this due to the minimal involvement of state representatives in mnemonic activities), ${ }^{7}$ one can hardly expect individuals to take the lead in active engagement with the difficult pasts. Apart from the political challenge involved, the socio-economic conditions and preferences make it too complicated for the people to get engaged with the past. On the rare occasions that it happens, it is almost always exclusively the work of a few enthusiasts. The improved economic situation, however, could change this situation. Another aspect of presentism that connects to current economic conditions is nostalgia, and we will talk about it later under the heading of 'individual past'.

Presentism, importantly, also serves as a strategy to downplay and silence the unpleasant memories of the past, or those interpretations that are not favored by the one addressing the difficult past. According to our findings, the reasons for adopting this strategy vary. In the context of intergenerational transmission, it may be an attempt to protect young people from unnecessarily engaging in debates that could be considered dangerous, or at least damaging to their contemporary societal relationships. This method of dealing with the past was particularly common during 'unfree' regimes. Some matters were simply not talked about then. However, avoidance, neglect, and silencing are not only a matter of the noted regimes. Even today, some matters might not be discussed (especially those whose actors are still living) given the older generation's fears that their descendants might become unnecessarily involved in political debates.

Another aspect of presentism worth considering is the silencing strategies of public bodies, and, of course, the strategies of professional historians. Without delving into particulars, let us highlight the fact that public, institutional or professional strategies of silencing make addressing the difficult pasts even more complex, and the conditions under which historical discourses and related practices are produced unclear and confusing. Therefore, it very much depends on the concrete agents of historical discourse production which past gets forgotten and which is remembered and how. That is, it is the social debate that, often in spite of the available factual evidence, decides which pasts will be present in the historical discourses.

We have already alluded to the socio-economic factors that form young people's take on the past. To summarize, there is a clear connection between economic conditions and opportunities for societal engagement where addressing the past, in many aspects, takes

Note that it took almost 12 years for public political representatives to make $17^{\text {th }}$ November 1989 the day when the Velvet Revolution in Czechoslovakia commenced - an official state holiday. 
place. What is important to emphasize is the complexity and interrelatedness of all three noted factors that condition young peoples' understanding of the difficult pasts. The historical discourses - whether stemming from texts, electronic media, a variety of public engagements, or the experiencing of sites of memory - are hardly separate from the practices (active or passive) that involve the addressing of the difficult pasts, or from the socio-economic conditions that create the differing opportunities for all those who, in one way or another, re-present the pasts. Addressing the ways historical discourses and practices are transmitted would be impossible without taking into account this complex quality of the 'present past'. Thus, instead of separating the textual, remembered, reenacted, lived, silenced, possible and impossible (in economic terms), it is much more viable to discuss the transmission of the knowledge and practices involving the difficult pasts as different aspects of the present-past continuum.

\section{Introducing the regions}

As has been noted, the knowledge and practices of our respondents with regard to difficult pasts stem from the complex relationship among the written, the remembered and/or experienced. In concrete terms, this includes the discursive entanglement of the professional history, the history in the school textbooks, and a variety of lay texts concerning the social memory, often laden with experiences. These three basic data-levels, as it were, inform the societal debate on the difficult pasts. However, they should be approached in a regional context as well, because the particular regional realities frame their production and availability, interaction and popularity as well as their content and its variations.

Our fieldwork was conducted in two contrasting regions of Slovakia: Rimavská Sobota in the south, bordering on Hungary, and Trnava, in the west. Yet, despite their contrasting character, most pronounced in the economic strength of the particular regions ${ }^{8}$ as will be illustrated later in this text, with regard to intergenerational transmission, differences in the content of what is transmitted and how it is transmitted are somewhat less visible. Historically, however, there are other differences that should be noted with regard to Slovak difficult pasts.

$8 \quad$ The Rimavská Sobota district is by far and for a long time the poorest district in all Slovakia, with the highest percentage of unemployment (over 30\%). It is an ethnically diverse region, with a high percentage of Magyars and Romas. In contrast, the Trnava district is one of the most progressive districts in the country, with the second-lowest percentage of unemployment after Bratislava, and a high potential for development due to the industry investments there (Peugeot, Citroen, Samsung). 
The Rimavská Sobota region, which, for a long time, formed the border between the Habsburg Monarchy and the Ottomans, was given a fresh socio-economic start after the decline of Ottoman power during the $18^{\text {th }}$ and $19^{\text {th }}$ centuries. Although the region was one of the core areas of rising Slovak nationalism during most of the $19^{\text {th }}$ century, giving rise to a considerable number of the first conscious representatives of the Slovaks [i.e., the new Slovak intelligentsia], after the break-up of the Austro-Hungarian Monarchy, the region, which had prospered mainly due to its economic connections to the southern parts of the monarchy and the capital of Hungary, Budapest, faced gradual decline. Its present state is the result of this gradual process. Another important matter to note, especially with regard to the difficult past, is that some parts of the region became, after the First Vienna Award (1939), a part of Horthy's Hungary. Thus, its economic decline was accompanied by political and ethnic polarization.

The Trnava region shared the glorious past with Rimavská Sobota. Due to its proximity to Bratislava, but also its own ambitions set against the dominance of the Habsburg capital Vienna as well as Bratislava, the Trnava region displays steady albeit sometimes interrupted growth. By the $17^{\text {th }}$ century it had become the center of education, and at the end of the $18^{\text {th }}$ century its dialect was chosen (although unsuccessfully in the long term) as a model dialect by the first codifier of the Slovak language, Anton Bernolák. Later times did not much change the importance of the Trnava region in Slovak contexts, and after the fall of the Communist regime, the region became, in economic terms, the most successful of all the Slovak regions struggling with the regime change and the new opportunities brought about by the Schengen agreement. Thus, when compared to Rimavská Sobota, it is hardly possible to speak about either decline or ethnic polarization. Trnava's is a firmly successful Slovak story.

\section{Conceptual framework}

Our conceptual framework is basically built around the analytic categories of the past, history (with its polemical debates), and memory. Since all of these are also categories of practice, we do consider practices attached to history, the past and memory as a related and necessary category to be heeded. Each of these has its own problems, as surely does our own approach. Adopting the insights of Birth (2006) and other analysts, we understand the past in terms of its connection to the present (see above and below), which allows us to address today's debate more precisely. Moreover, paying attention to how the present shapes the past is imperative if we want to address the transmission of the knowledge and practices related to the past across the generations, especially if the subject of our research is the process of transmission among the current generations. 
There are several reasons for addressing the transmission of historical knowledge and practices via a past-present continuum. It has been already noted that the past appears through interrelated sets of source-materials, which take the form of written text and memory (social and/or individual) that in turn are laden with different kinds of experiences. It is, however, far from clear how these are interrelated, although it is clear that understanding them as separate domains capturing the past does bring about a rather arbitrary and incomplete knowledge. The problems of authorship, intertextuality and social construction (see BARTHES 1977, KRISTEVA 1980, BERGER and LUCKMANN 1966) destabilize the credibility of the written and direct our efforts to finding the best-fitting interpretation. The problems with memory - of what is remembered and how, and what is not and why, as well as how what is remembered, publicly or individually, draws from what is written - direct our efforts at understanding the past, for one thing, to the mnemonic and cognitive processes of recording the past, to its social contexts, to the dynamics between the written and remembered, and, for another, to fitting interpretation again. What becomes clear is the intersubjectivity of our interpretative efforts, which cannot avoid the present right because they seek to understand the past.

The current as well as past social debate on the past, and particularly the difficult pasts, can be approached via the post-structuralist goal of "cultivation of the details, accidents...or minute deviations" (FOUCAULT 1997:142-144), by being sensitive to the debate's social contexts across time and space, and to the claims of credibility that in one or another way involve a response to power (CHAKRABARTY 2000). Observing the current debate on how the past is to be viewed among Slovak historians (LIPTÁK 1997, HOLEC 2007, and MICHELA 2011), and with regard to the dynamics of written and remembered, there is a clear need for a social history of Slovak historiography to elucidate the missing connections between how historians evaluate the past and how people remember and construct it.

The transmission of difficult pasts across generations - the transmission of ideas, ideals, thoughts, memories, and the practices related to all of these - would be unthinkable without heeding the suggested complexity involved in how the past is talked and written about. Yet, how are we to distill anything concrete and reliable from the vivid and experienced complexity in which the people's pasts reside, from the liquid modernity (BAUMAN 2000) that uproots grand narratives and offers fragments of understanding instead? If memory, as the societal repository of narratives on past and individual recollection, forms an alternative to the researched knowledge of historians (c.f. OLICK and ROBBINS 1998) even as it simultaneously forms and conditions the historians' habitus (BOURDIEU 2005), the transmission itself appears to be the problem (and therefore we call for the social history of historiography) that should be discussed first. But memory in 
either of its forms is also tightly connected to processes of learning. Some of it is learnt (via texts, via recollections), and some of it remembered (if primarily or secondarily experienced). Without direct access to experience of the remembered event, the memory (as a complex of the written and remembered data) is first learnt and only then remembered. Yet, however we try to untangle this complex knot of learning, recollecting and remembering - through which people's pasts are woven - we cannot avoid the fact that the past is constantly being constructed and re-constructed according to the preferences of and within the contemporary power-settings of current societal discourse (FOUCAULT 2004[1975]). So, if we are to talk about a concrete societal discourse on the past that aims at the past's transmission, and, for this paper, localize it in post-socialist Slovakia, we will necessarily end up again in a polarized debate on the past where memory is in opposition to the authority of the so-called official historical narratives that Assmann and Shortt (ASSMANN and SHORTT 2012:4) saw as a primary characteristic of societies in transition.

However, the polarized debate on the Slovak difficult pasts (see more in Historicky časopis 2004/2, 2007/1), will not concern us here. Much more important to understanding how the difficult past is transmitted across the generations is the question of the relationship between transmission and transition that also brings us closer to the subjects of our research - the people of post-socialism. If people's pasts are constantly constructed and reconstructed, and if we learn, interpret, produce, remember, and recollect it, how has political change (such as the change from socialism to liberal democracy) affected our knowledge and practices related to the past?

The socialist regimes imposed strict regulations ${ }^{9}$ on how the past could be transmitted. In fact, the past was openly used as an ideological tool. ${ }^{10}$ Whatever was published, whatever was publicly remembered, had to conform to the official ideological framework that, put simply, elevated the role of the working classes led by Communists in the evolution of a given society. It is obvious that this ideological framework, which was, after the fall of the Communists, mainly replaced by nationalism and post-socialist liberalism, did not disappear all of a sudden, just as the regime and its lived outcomes did not disappear. In fact, it is highly improbable that anything disappeared all of a sudden just because of the political changes. What actually happened, and what happened with the both

9 Ignoring or transgressing these regulations could mean the end of one's career, or eventually a ban on any publishing activity, and political persecution, which was often extended to the transgressor's family members.

10 That does not mean that the past is not used as an ideological tool nowadays. Far from it.

DOI: 10.1515/eas-2015-0007 C University of SS. Cyril and Methodius in Trnava. All rights reserved. 
the professional and lay people's engagement with the past, is therefore rather a question, as is the question of what continued and still continues to form and inform this engagement, pursued nowadays (PRICA 2007, BUCHOWSKI 2006).

When discussing the transition (from what and where to what and where?) it is therefore highly important to give voice to post-socialist subjects, the people of socialism engaging with the new political era, who are often forgotten in the debates on the political changes in Europe after 1989 (PRICA 2007:177). Was "Homo socialism", if there was one, different in his approach to the past from his current counterpart? Is any "Homo socialism" still present? Is there any "socialism mentality" present and, if so, what is it? Our approach seeks to show how these labels deconstruct themselves as soon as they are set in the ethnographic field. It is an approach from below that aims to fill the lacunae and inquire for the social history of its development.

Family memory, and the memory of older generations in particular, certainly plays an important role in people's engagement with the past-present continuum. The family and older people introduce youth to societal ideas that spring from the past and live in the present. The processes of transmission of knowledge and practices related to the difficult past, whatever their complexity, might therefore help us assess how young people understand the past. Moreover, the transmission that we are going to talk about later has been significantly formed and informed by the processes of transition in post-socialist Europe. People to whom we addressed our questions, and whose social environment we observed, are the people of the transition generation. How then does the transition, the earlier and the new era, affect the past that is transmitted across these peculiar generations whose peculiarity is in being the observers ${ }^{11}$ of transition? What gets transmitted, in what form and with what contents? What doesn't, and why? Moreover, events are remembered and sometimes commemorated, but how much 'memory' remains across time, across generational discourses, individual changes, and learning? What really gets transmitted and shared? It is one thing to keep something in memory, another to share what is kept. The latter may vary according to the situational discourse in effect during the occasions of sharing. These are the questions that we will try to answer below.

\section{Note on methodology and collection of materials}

Our research methodology was designed to elucidate the dynamics between the written, the remembered, and the experienced. Therefore we mainly opted for in-depth interviews with

11 I.e., those, who could in some way happen to learn something about the previous regime.

DOI: 10.1515/eas-2015-0007 C University of SS. Cyril and Methodius in Trnava. All rights reserved. 
the older generation, who were, if possible, the relatives of our earlier respondents in the two regions introduced above with whom we conducted the focus groups debates. ${ }^{12}$ The interviews were preceded by the study of history and current social conditions (with the help of surveys done by the sociological part of the UCM research team) of the noted regions and later accompanied by the ethnographic observation of the terrain (local and regional sites of memory) and its photo documentation.

However, during the research, we faced a major problem in accessing the older generation relatives of those students who had participated in the focus groups. It is difficult to assess the exact reasons for the students' lack of interest in mediating the extension of our research across their families, but among the reasons that we could sense from our communication with the students was clearly a 'lack of time' and the students' general unwillingness to involve their parents in activities external to their school duties. But after all, these reasons are telling in their own right, displaying the public's general lack of interest in historical questions, and possibly also their doubts about sharing private memories related to the difficult past with any public person.

The problem was partly solved by a helpful student's distribution of our questionnaires to parents and grandparents. In this way we were able to collect at least three filled questionnaires directly related to the focus groups. With the help of another student, who, however, wasn't a part of the focus groups, we obtained another twenty-two filled-out questionnaires from the Rimavská Sobota region. These form one part of the collected materials.

The other part consists of seven in-depth interviews, each approximately two hours long, conducted with the families of the Rimavská Sobota and Trnava regions whose children are approximately the age of our focus group respondents. In two cases we interviewed two generations (i.e., parents and grandparents), and the others were either a parent (3) or grandparent (2). Overall, the respondents came from varied social strata (from people with basic education up to university educated), but most of them were firmly tied to their present region, usually by family relations.

Although we understand the limited character of the noted materials, they reveal potential answers to the questions on transition and transmission posed above and vividly capture the ways in which the people of the regions address the past. Moreover, the

12 The results from our earlier research have been summarized here http://www.fp7myplace.eu/documents/Partner\%204\%20-\%20Slovakia_deliverable_2_1_submission.pdf. 
interaction between the parents and grandparents allowed us to observe how the past is shared across three generations.

\section{Transmission and family mnemonic culture}

Transmission of the knowledge and practices addressing the difficult past within the family is a complex process that reveals the mnemonic culture of the particular family. There are several important factors in this process. First is the method of transmission. From our materials it seems that sharing the past is rarely a matter of conscious or planned engagement. Rather, as different occasions arise, people share what they remember, and different reasons to address the past arise, too.

"Well, when one is on holidays, or doing trekking, then you may see a board [telling something about the past] so naturally you get interested in [what it says]. But this is hardly a practice of daily life ... Usually, when we get together, our grandma starts with something. She is a kind of 'memory-carrier'. She stars recollecting how life was difficult then and how it is easy today." (SVKTTR1-mother)

"When we sometimes succeed to meet [as a whole family], then there is an occasion to talk [about the past]. We told them [the children] about $1^{\text {st }}$ May, how we went to demonstrations, how we were rehearsing for Spartakiad ${ }^{13}$...” (SVKTTR1-son)

"Sometimes something was mentioned, then we talked about it and it could happen that the debate was even long. [The children] were curious to know how it was during the earlier regime and what I remember from 1968 and before..." (SVKRSR3)

"During some debates, or on some occasions, when we get together as a family, we talk about who was who and what he/she did in those times." (SVKTTR3)

"For instance when there is a problem, something should be resolved, so I narrate how my father handled the restitutions, how he had to fight for so little, visit the offices..." (SVKRSR2-son)

However, the occasional is not the rule. The respondents clearly indicated that they sometimes share their knowledge purposefully, not just when the occasion arises. The purpose may be understood as a family mnemonic tool designed to educate the following generation, to provide it with experienced pasts - the pasts the family fashions according to

13 A mass gymnastics show held once every five years in order to display, among other reasons, the physical preparedness of socialist youth to deal with the 'building of socialism'.

DOI: 10.1515/eas-2015-0007 C University of SS. Cyril and Methodius in Trnava. All rights reserved. 
its current needs. Thus, the primary reason for sharing the elders' past seems not to be the transmission of the factual past, nor of the family narrative, but the sharing of knowledge as a practical tool for the children's future. This is where the interconnectedness of the past with the present is evident. This is also how the alternative to official pasts develops. It is the alternative that, irrespective of its differences to what may be read in the textbooks, infuses in the younger generation the ability to resist the official - the bookish - and directs them to rely on their own individual judgment. Such purposeful sharing of knowledge is definitely not exclusive or rare in general terms, and does not concern only the difficult pasts, and when seen in the context of the current polemics on the times of being 'unfree', it is certainly instructive in matters of the individual approach to debated social themes, as well as in terms of the shared details.

"We watch [on TV] many history programs. We talk about the future, about what is waiting for this current generation. [We talk] about what they will have to pass through and about what we could get. [For instance] Being a member of a housing cooperative society I could get a flat, I had the certainty of having a job ... that there was a right for employment [implemented] that stopped functioning during the nineties... The younger people should at least be able to imagine [the communist past]. I am not sure how they can do it, but they should have at least some information about how it was ... for example, when somebody tells them about the previous regime, what they can see in it [i.e. how to react to such talk]." (SVKTTR3)

"Of course! We always say you have to remember this [i.e., the old times as seen by older generation] and from your young age, you [also] have to remember how your own life went." (SVKTTR2)

„No [we do not discuss the periods marked as important by the historians]. [We discuss] those from our lives. How we were "zväzáci" [members of Communist youth organization], how we were doing various kinds of activities... That does not exist today ...people were young, they supported each other, they had fun, they had skills ... “ (SVKRSR4-daughter)

Yet, transmission has its own problems. The younger generation may not believe the narratives of the older generation, or may even ridicule them. Therefore, as suggested above, it is disputable what, in fact, gets transmitted, and why. The situational framework is difficult to avoid, and although some generalizations can be made (like, for instance, that the older generation offers alternative interpretations to historical discourses young people meet with in school, or provides details available only within narrow societal, perhaps only familial, circles), without repeated checks of the transmitted matter in the ethnographic field we can only guess at which major themes are transmitted. Such uneasiness reflects our 
earlier observation that it is not just the past that is difficult, but it is the social debate that addresses the past which makes the latter difficult.

"These young people, you know, they hardly accept [everything we told them about] what we lived through. They do not need to [face it].” (SVKRSR2m)

"Well, they laugh when I mention something [from the past] during our discussions ... Sometimes they accept what I say, but often they have already formed their own opinion, so ..." (SVKRSR3)

The difficulty of accurately judging what really gets transmitted is illustrated by our observation that the generation of grandparents and parents of our young respondents held different opinions on the same transmission of content. The following quote shows that although the mother was convinced of her role in the transmission of memories related to 1968 (the so-called Prague Spring and occupation of Czechoslovakia by the armies of the Warsaw Pact), her son held quite the opposite opinion. Yet, as seen from the quote, he had already taken his stance on 1968 .

"I have, for instance, talked about 1968 with my children, because it was a matter of heart for me. My final high school examination took place in June, my marriage date had been set to October and in August the Russians came. Everybody was saying 'do not get married, there will be war', so we wept, but despite the situation we got married [even though we lived in a constrained situation] and were taking supplies of flour and one kilogram of rice. Also clothes were very moderate. So I was telling them how this [1968] turned all my life upside-down.” (SVKTTR1-[grand]mother)

"When we were children nothing much was spoken about it [events of 1968], because it was during socialism. You know, father was in the Communist party, so he also could not say much on this. That time generally nothing much was said on 1968 in public, as to what exactly the Russians came to do here, whether to make us free or push us somewhere backwards...” (SVKTTR1-son)

Consider another example of the constraints related to studying and practicing religion. Here again we may see disagreement between the generations. Apart from documenting the forms religious practice could take in a Christian family with a Communist family member, it shows how knowledge about the experienced reality may be misunderstood by the younger generation.

"Well, when I wanted to go to the church, I went. When I wanted to put children for the religious education, I did.” (SVKTTR1-[grand]mother)

„That wasn't a problem. “(SVKTTR1-son) 
„It was! Because daddy had to go and sign certain papers, since he was a member of the Party. Every time he wanted to enroll a child [for religious education] it was a trouble. At last when he enrolled the youngest daughter he had to unenroll the oldest son." (SVKTTR1-[grand]mother)

Another example documents how disagreement on the difficult past influences discussion around it.

"The boy laughs at me, saying "father that time it was necessary to act somehow [in order to earn money]. You shouldn't have just sat [and accepted the regime]." Well, but we were taught like that and that's why one did not need to fear. While doing my high school exams I had already known that I would have a job. Now, when the child finishes the study it faces a problem." (SVKRSR2)

Transmission, however unlikely it might seem, is also economically conditioned. The particular conditions might relate to the times of economic depression, such as those of the war/after-war times, or to a general lack of financial sources that would facilitate a stronger connection to the pasts.

"The problem was that we were too many children. It was necessary to make up our living. Well, father was as he was and mother, if she wanted us to survive, was all the day at the field, so by the evening she wasn't really feeling like talking on, say, the Second World War. ... We [as teachers] would love to go somewhere to visit historical places, but there is no money for the journey, entrance. If the school supported us we would definitely go, if we had money, there wouldn't be any problem." (SVKRSR1)

To sum up, we were able to get some insights on how the transmission of the difficult pasts is conducted across the generations. But even here the issue of what actually gets transmitted is problematic, since sometimes the young people hold different interpretations of the same pasts. From our materials, it is clear that the families do talk about the difficult past, do engage with the younger generations and instruct them on the knowledge related to the past, whether occasionally or purposefully. But they do not do that for the sake of clarity of any vision of the past (see the later discussion on presentism), but rather for the sake of preserving the family memory in order to instruct their descendants, so that the transmitted knowledge might help them deal better with current and future challenges. These challenges are often envisioned as economic ones, in terms of employment and the ability to make life meaningful and satisfactory.

Here, perhaps - but among our respondents we found no evidence to support this claim - the political heritage (i.e. the political stance of the older generation) is transmitted to the younger generation. In fact, as we will show below when giving the examples of how 
older people compare the present and past regimes, it seems that the confusion of current historical discourses on difficult pasts adds to the general political confusion, and leads instead to apathy and lethargy. The transition generation, the generation that was brought up in one political ideology and must now live in another, is suddenly expected to have a firm political stance and even to share it with its younger generation. What should perhaps be addressed is how people can, in the face of political and/or economic transition, develop firm political views - in this case, the same people who in most of their public engagements were either silenced or in their own ways negotiated the espousal the official Communist ideology. Moreover, the overwhelming dominance of the state agency in all public matters, the penetration of the regime into all public and even individual policies and social engagements has formed a generation that, as we will show, still relies on public/state involvement in organizing the conditions of their lives instead of taking the issue into their own hands. Therefore, the matter of what is transmitted gains greater importance the more we see its complexity. The following quote illustrates that the sudden breakup of the ideologized life that the people of the difficult past experienced and now attempt to convey to their children is seen as unproductive, as creating confusion and hindering development. This is where transmission and transition meet.

"I think that every government, every society has its own vision, has its own truth and in fact it should have it. Moreover this vision should be a long-term vision that does not change too often, after each election, because this is what is wrong in our state. Each government has a different vision whether we observe it in the health sector or internal affairs sector, or social sector; always there is something different, new, new laws, new regulations. Sorry for saying this, but people are stupid from this, i.e., what is valid, and what not. It is all changing too quickly. Something started and then the new government comes. Then everything from the previous one is bad - they are bad, they do it wrong and we know what the best is! Hence everybody is an expert and every politician is an expert for everything (as long as he is in the right party at the right time). Take the example of ministers. In one government he is a minister of one department. Then the same government comes, same party wins elections and makes the government and he is a minister of a different department. So what kind of expert can he be? Either he understands something and then let him govern it, say, even 20 years, but this is ridiculous that during one term he is the minister of public transport, for another term minister of finance and for a third, minister of state economy. I know he is a political appointee, his is a political responsibility, but he could have understood, seen into, something, couldn't he, and not just been cheated by his advisors! This is a joke!" (SVKRSR1)

The complex of 'discourse-memory-practice' intertwined with the family-cum-public environments where one learns about the difficult pasts (as well as learns what to 
remember), is well illustrated when we heed the respondents' opinions with regard to history education. The reliance on the state is clear also from the respondents' criticism of education, particularly education seen as an introduction to the country's past. There is a clear sense of 'lack of education', or a 'decline of education', which, according to our respondents, results in ignorance concerning the local (and also regional and national) past. In the current society leaders are charged with unprofessionalism and with lacking even the simplest unifying vision of the society, and are also blamed for the neglect of the past. Consequently, the transition itself is then doubted, because what people of older generations seem to experience in current times, and what is vaguely called 'building a liberal democracy', lacks, to their eyes, any common goal to which they were so much used for most part of their lives. The neglect of education (c.f. underfinanced educational system in KRATOCHVÍL 2011:203) is also linked with the neglect of any instructive past, i.e., the past that they expect the state to instruct their citizens about.

"Nobody is interested. Nobody tries to develop anything that should be remembered. Nobody tries to teach [about the instructive past of the country, to which people were accustomed during the previous regime], nobody presents [the instructive past] in newspapers, media, television or radio. Children do not know why there is $1^{\text {st }}$ May, why $8^{\text {th }}$ May, why $29^{\text {th }}$ August [Day of commencement of Slovak National Uprising in 1944], why there is $1^{\text {st }}$ September [Day of First Constitution of Independent Slovak Republic] and what all these mean. They only know that these are holidays." (SVKTTR3)

"I was taught by one teacher of literature, Števko. We were expected to know all the names of national figures [who were also literary figures]. Currently this is missing. [Children ask] who was that, who was that? So, why it is not taught?" (SVKRSR2-mother)

"The education system was at a certain level [during the Communist regime]. It was paid well and the University education was considered much higher. Today, they made it degenerated. Anybody gets University education today. In order to save education in the face of a declining population we produce a high number of University-educated people but not those whose capabilities correspond to the highest level of education as the University education should be. ... Whole society is responsible for this decline [of historical knowledge], not only the educational system, although the latter plays its part in the process. Nobody really cares about the current state of affairs. When we watch some news, reports, some politicians talking, nobody seem to be active in this field. Everybody prefers only his own interests, whether within the party, or purely individually. " (SVKTTR3)

„Well, it would help them [young people] to know [the region, country] from where their parents came, to know how our society is, what its roots are. The Slovak Republic is not just a piece of brick fallen on the ground. It had its own evolution: it evolved from 
something. [They should know] that there was something before [our current times] and also more remote in the past; that there were princes Moymir and Pribina and other such people. I am not sure how many young people today would know who these people were and whether they would rather just speak about Pribina RI [a name for one of Slovakia's highways]. I just think that it is like this. These themes [historical with regard to evolution of the state aspirations of Slovaks] are hardly spoken about in classes. As far as I remember, we used to go for school trips to experience history every year; we did not go to swimming parks. Today, I do not know about many such educational activities [organized by schools]." (SVKRSR1)

\section{Sites of memory as the matter of transmission discourse}

Admittedly, the sites of memory are the repositories of the past, and they help younger generations experience the past in a much more immediate way than textbooks or history classes at school. Although, overall, our respondents admitted the importance of historical sites for the transmission of historical discourse, for the people of the older generation it is often the local sites that embody the past they want their descendants to know about. The previously noted reliance on the strong public body, or, in the terms of our respondents, the state, is also significantly present where their opinion on the relevance of sites of memory is concerned. So, while they recognize the importance of such sites for the education of the children in historical matters, particularly those that relate to difficult pasts, they question the current state of the sites, which they often find unheeded and publicly neglected. This situation they interpret in two basic contexts: diversion of economic sources from public to private interests, which then causes the deterioration of the sites and results in a public lack of interest in public matters generally. Both are directly connected to transition and transmission.

The first context illustrates the inability of the post-socialist state to secure public property. In other words, the overwhelmingly state-supported (sic!) neoliberal economic philosophy prefers market forces to regulate public property instead of the state. The second context illustrates the unwillingness of the public to actively support the public sphere (including the care of public property), which seems to result from the people's misinterpretation of the public sphere that, with regard to property, they often relate to "Communist's property of all". Moreover, this unwillingness can be seen as a reaction of a public only recently freed from the compulsory attendance of symbols of past (used by Communists for their own propaganda) that the older generation experienced during the previous regime. However, even if the new regime brought the freedom to decide whether to join in public activities (like visits to public memorials) and delegated much of the economic care of the sites of memory to regional elected bodies, our respondents, in 
relation to their own children's education concerning the past, seem to oppose such a state of affairs. Neglect of the sites of memory is for them a symbol of the absence of any societal goal.

“My son's generation does not understand why they should go and place the garlands... They do not understand that this is a site of memory [pamiatka] or that it commemorates $1^{\text {st }}$ May or $8^{\text {th }}$ May. We lost twenty years [in neglecting these sites] and even if today there are attempts to change this state of affairs these attempts mainly reflect the activities of individuals who just want to show up [and amass their own socio-political capital]. The original meaning of commemoration and showing respect [to our predecessors] has been gradually lost. It is not as it should be. By pushing off the whole period of socialism we created a vacuum [of memory]. It [memory, the past we should remember] is not important. We opt for different strategies [in context to past] where these memories, or building of patriotism, or national pride and creating conditions for interest in history has no place. ... This era has brought just one criterion - economic. You have money, you can do anything, even if you are ignorant [i.e. you do not know anything about the society's past]. Nothing is compulsory." (SVKTTR3)

"They [sites of memory] will get destroyed on their own. During the Communist rule they were beautiful, they flourished, the flowers were planted, the garlands ever present. Between Zarnovica and Nova Bana there is a memorial on the left side of the highway, go and see how it looks now. In the past people came and talked there, today, if they come, they just put garlands and leave. Nothing is done to attract people.” (SVKRSR1)

"These days the school trips are rotten. Nothing much gets organized. Everything needs to be paid for, but parents are unemployed, so...?” (SVKRSR4-daughter)

"We used to go for these trips, here and there, every year." (SVKRSR4-mother)

In the conditions perceived by the older generation as public neglect strengthened by lack of public sources of economic support of sites of memory, it is the family that takes the initiative to introduce their children to the past it considers important for them to know for their own benefit.

"When the children were smaller we used to go. Today they go themselves. They go for a walk, stop and like that. Also the last time, when we were coming together back from the visit of friends we said that there is [a memorial to] Vansová [well-known author of literature], so we talked about her and finally stopped to see the memorial. My daughter was interested, the boy not that much. She needs to know [about Vansová] if she is to teach in school [after she finishes her studies].” (SVKRSR3) 


\section{Themes of transmission and the individual past}

Since we recognize family memory as a vital and important part of historical discourse to which the younger generation is introduced, let us look at the themes, or contents, of shared individual pasts. They display the individual memory choice, i.e., they display what is chosen to be remembered, what is attempted to be shared, and what is silenced and passed over. The most important parts of these individual pasts that live their own lives in the memories of the younger generation, are those where the past is compared to the present.

First, we will highlight what seem to be the dominant themes of individual memories of difficult pasts and then we will turn to comparisons. On the one hand, the dominant themes [i.e. difficult pasts remembered] suggest that the individual past, although entangled in the learnt, and to a certain extent ideologized, interpretations coming from various types of media, display a rich detail that escapes purely ideological interpretations. The comparative narratives, on the other hand, display the individual approach to a previous regime that was necessarily shaped by the individual experiences. These form the alternative view that the family memory offers to younger generation vis-à-vis the public historical discourse. Most of the themes that appeared while debating the authoritarian regime, as is evident from our participant observation, concerned the Communist regime. The emic category, however, wasn't "regime", but rather "those times". The Slovak State (1939-45) that we earlier identified as another difficult past wasn't primarily mentioned when respondents were asked about the unfree periods of their past. The reason for this should be sought most probably in the fact that the period of 1939-45 is, even for the older people of current days, too remote in time. However, when our oldest respondents were directly asked, they willingly recalled at least some reliable memories, some of which, importantly, were also shared memories from their parents.

The war and after war memories present an ambiguous picture of those times that may help the younger generation to recognize alternative interpretations, and also see how human agency determines what is remembered and how.

"Take, for instance, how they speak about Germans [as fascists, as occupants]. There was a field kitchen near to our house and we used to visit it as children. The cook [German soldier] gave us sweet coffee, for Christmas there was a celebration, Christmas tree ... well on the one side they were bad [soldiers of occupying army], but on another..." (SVKRSR2-grandmother)

“Those who remember the Slovak State say that it was a good time to live.” (SVKTTR2)

"As far as the Slovak State is concerned, my mother said that from the point of view of a common man it was a very prosperous period. It was also a quiet period. No hunger, not 
many problems, only when the front passed through. Theirs was an experience that when Germans were retreating they showed as polite people, who greeted the locals, sometimes engaged in talks, and did not do any garbage. On the contrary, Russians were quite the opposite. Their behavior had nothing to do with politeness. So, it was an unfree time, for sure, but well, she knew German, she used to grow vegetables and sell them in Austria as a small girl...” (SVKTTR3)

In the above narratives the local context conditions the war memories. Western Slovakia always had closer a relationship to Austria than did other parts of the country. Moreover, the war did not affect the western parts at the same intensity as, for instance, central Slovakia. People from the Rimavská Sobota region (Hnúšta), and a lady originally from northern Slovakia (who came to Trnava only after her marriage) had rather different memories.

“There were also 'gardists' [members of Hlinka's guards, paramilitary Nazi-oriented organization during the Slovak State] in our village. They were deporting Jews, among whom I had a few friends. Alice, Edith, they were such nice girls...In our village there were only eight Jewish families ... When I go to sleep at night and cannot sleep I have our entire village in front of my eyes." (SVKTTR2)

"I remember well how Hlinka's Guards were aggressive. When there was a deportation [of Jews], here near the bridge lived a Jewish family, such good people they were. One, who was from the Guards said 'go away you Jew' and kicked the Jewish lady ... she waved to us while passing through the streets ... He worked as a school caretaker. After the war, he kept in his room pictures of both Tiso and Gottwald [President of the Slovak State and the first Communist President], so you judge what kind of man that was." (SVKRSR2)

„This is all modern [the interpretation of Slovak State] to put the whole Slovak State period, as it were, into a box. Also to call it a fascist regime and that all is bad. We do not distinguish between the parts, do not separate the good and bad parts. Put simply, as soon as in that regime appeared paid deportation of Slovak Jews, then everything is bad. Nobody asks what is it that happened, what kind of laws we had, what kind of certitude there was. What about currency policies, deficit, opportunities to buy something? It is modern to press everything to a whole and either to elevate it or throw it down. And even today, the whole totalitarian system from 1948 to 1989 was bad. So now we head to a different destination. Only we do not know where." (SVKTTR3)

The most interesting and important narratives that we recorded are the comparative narratives. They, perhaps, best reflect what is in fact transmitted during the transition period, in which we, to a great extent, still live. They contain nostalgia, as well as presentism, criticism of the socialist regime as well as appreciation of its economic 
certitudes or the much more systematic and organized public engagement with the past that many people miss today. They illustrate the cry of the older generation for a missing common societal goal as well as a lay judgement of the times in which the older generation lived the greater part of its life. Importantly, they display the complexity of the past and thereby put the academic notion of complexity into the ethnographic field.

"No, I would not say that the regime tied my hands. I lived a better, easier life. Perhaps Communists made a mistake in prohibiting religion and freedom of movement, but as far as the social conditions of our lives are concerned I cannot say it was bad. I could earn enough, buy everything that I needed, save money." (SVKRSR3)

"For instance I recall that families were visiting each other more often ... now, I meet with my cousin, hello-hello, how are you and that's it. People used to meet much more, talked more to each other. Now people have more worries, so they come home, close the door and put on TV." (SVKRSR2-son)

"From my point of view there was no any authoritarian regime. Everything worked; everything had its own system. When people speak about authoritarian regime they perhaps mean that only one party was ruling. ...I can't say anything bad about those times... System of work, of education, of social certitudes, of health - all that was something completely different. Now a new era has commenced. The era that still draws from those socialist things and cannot cope with what comes as new." (SVKTTR3)

"I was brought up in that [regime]. I never thought about it as an authoritarian regime. I was reconciled with it and it suited me. There was nothing else to compare it with. ... They [Communists] certainly did something wrong. ... No government can say that it is $100 \%$ good, such a government does not exist in the world. So they were also making mistakes, but if I compare what was then and what is today nevertheless it was easier to live. What's the advantage of opportunity to travel for holiday to Spain, to Dominican Republic and wherever else, if one has not money for it? Well, let people come here [to Rimavská Sobota region] and let them find a job. Here people, including me, work for 300 Euro. Therefore I have to say that the past regime was much better for the people. Everybody had work, built a house, could afford a holiday cottage ..." (SVKRSR1)

However, a parent in his forties claimed quite the opposite.

"It was a dictatorship of one party; everything was censored, personal freedom limited. Yes, it was an authoritarian regime." (SVKRSQR3)

Apart from the generally positive evaluation of the previous regime and expressed nostalgia, we observed that what appears to be a positive evaluation stems from people's efforts to keep a balance in their view on regimes as such. Many respondents spoke about 
how every era, every regime, has its pros and cons. This effort to provide a balanced view displays one important characteristic among the transition generation. Whatever was mentioned with regard to life under the previous regime was not apparently directly connected to the authoritarian character of the regime as such. Quite the contrary: several of our respondents lived through several regimes (war, after-war, socialism, post-socialism) and they found it necessary to repeatedly adapt themselves to the prevalent socio-political conditions. This attitude can be illustrated by the people's approach to the Communists' efforts to organize people's lives as intensively as they could afford. Public holidays were one of the best ways to engage people in the narrative of communism-building. They also documented how social life was organized. But it would be too naive to state that the Communists succeeded in their efforts. Our findings show that something new - a hybrid of the ideological organization of public life and the actual manifestation of the organization in which ideology was compromised - was created. The attitude toward collective gatherings therefore cannot always be negative. It is a collective that makes a gathering, not the regime (and perhaps that's why that attitude is worth sharing with the next generation).

"So we sang: Hlinka's Guard, Slovak Guard, Hlinka is our father - at that time, children were having fun [with these songs]. Afterwards we became Pioneers [and sang pioneer songs]." ${ }^{14}$ (SVKTTR2)

“ $1^{\text {st }}$ May - Nobody minded it. There wasn't any school that day. We took it as a good day. We passed along the stage [with Communist representatives], threw away the wavingequipment [e.g. flags, flowers, portraits of Lenin] and went home. When bigger, we went to have some wine and that was it. ... SZM [The Socialist unity of youth - an organization for high school and university youth, something like the Czechoslovak version of Comsomol]", well we did not take as compulsory everything that was concerned with it. We were members, so we organized discos, functions, such kinds of activities, because there were not other such youth organizations. We had a club and so we had somewhere to go. ... even if there were some agitators for the Party, we had fun from them. We were not taking those people seriously. Perhaps if we were older, the situation could be different. The regime did not affect us." (SVKTTR1-son)

"Well, in my own village, we used to go for functions. Earlier it was a much richer public life. Easter, it was a must. Also theatre was played, cabarets and the like. Nowadays there

14 The Pioneer organization was a Communist youth organization that prepared young people for their role in socialist society. It was automatically expected that students in grammar schools would join the organization. Rejection of the offer could mean various kinds of problems for the particular child's parents.

DOI: 10.1515/eas-2015-0007 C University of SS. Cyril and Methodius in Trnava. All rights reserved. 
is nothing. Silence, there's nobody [to organize anything]. Young people are not interested." (SVKRSR4-mother)

"It was good, even that SZM, young people, activities and not only the regional activities...” (SVKRSR4-mother)

Out of the narratives that displayed the balanced view, perhaps this one best captures the efforts of the older generation to explain how they accepted the regime even though they were aware of its disadvantages. This is a kind of nostalgic realism.

"I cannot say anything wrong [about the previous regime], because there was employment if I compare it to current days. I am an old man, my pension is more or less sufficient and something I can grow in my garden till I can. At that time there was no unemployment, everybody had a job. Even if the money was less, I could afford much more than today. I do not know whether it was better, but somewhat feel it. Of course, there was socialization [into party ideals], collectivization. ${ }^{15}$ My father was a peasant, so they took everything from him. ... But I would not work on land anyway, I had my schooling. My wife was a teacher studying pedagogy. Her father also did not join the cooperative farm, as mine. We therefore could not get a flat. Well such a time it was...” (SVKRSR2)

The vivid details that these narratives present and the balance their narrators attempt to achieve may, of course, not always lead to positive feelings for the narrator. The realism, although an important feature of what is shared with the younger generation, sometimes results in an inability to positively evaluate life experiences related to the regime. Moreover, for those who lived in several regimes, it is the regime itself and the regimechange with all its applications and influences on the life of a common man that is important to heed, remember and share, and not the character of the particular regime itself.

"My father was a peasant's son. His father died in 1947 and because he was child of [rich] peasants then the system touched his life in the following manner. He could study, only what they allowed him. So he did his high school at agricultural college in Bernolakovo and later when the tough times were lighter, in the 60s, he could study at Agricultural University. So what he would anyway lived through [as a rich peasant's son] that he studied. In order that he was allowed to study, finally he joined the party. ${ }^{16}$ Perhaps also

15 The politically instigated process of forcing peasants to join newly-made cooperative agrarian farms (similar to Russian kolkhoz) and give their land over to the collective ownership of such farms.

16 The children of rich peasants were usually not allowed to achieve higher education unless they compromised with the regime. Also, important in this context is to note that rich peasants were

DOI: 10.1515/eas-2015-0007

(c) University of SS. Cyril and Methodius in Trnava. All rights reserved. 
from some kind of inner conviction [after-war times] and also for being able to work [later in the 80s he became the director of a cooperative farm]. This has all come back to bite him in the 90s [He was blamed for being a member of the Party]. So, the regime [sic!] grinded him twice. From the lowest storey he climbed up by his own efforts and for that he had to join [as rich peasant's son] the Party and later, because he was in the party the system [regime] pushed him down again. He ended as a worker." (SVKTTR3)

Such life experiences lead the people to question the basic categories that are socially constructed in order to explain and provide meaning to people's lives. These questions are also passed to younger generations.

"I ask, what is freedom? It is a different thing for everybody. For some it is that they can do whatever they like, can go wherever they wish. But no society allows people to do whatever they want. Every society has its own boundaries, borders within which one can move. Freedom thus is bounded by the surrounding environment and by society. Even some people today who would like to have more of it, they won't, because the society and its laws would not allow it. Of course, in those times people were prosecuted if somebody said anything against the Communists, some matters were really too tight. I have no problem to agree with this.” (SVKRSR1)

"The European Union, Brussels, they force us to accept whatever and our "elites "[papaláši]" just agree. In this respect it [EU] can be seen as authoritarian. The Party [similalry] said that this is it a that was it. Earlier there were five years periods for planning how the economy will run. Similar thing is done by Brussels today. That was a socialist thinking: this state should produce this much and the other that much." (SVKTTR1-son)

Moreover, there is not only a questioning of current times and the related explanatory models (such as 'today is democracy, we are free and that is worth all the shortcomings of the current times'). People do have new experiences and see into the applications of these models. Their discursive as well as practical contexts lead some of them to active engagement with the current socio-political environments.

"I am trying, not just for myself but regarding the salaries and other advantages that we workers are entitled to enjoy according to the law. However, our employer says that

severely persecuted by the Communists, so either people opted for some kind of compromise with the Party, or were completely socially and politically ostracized.

17 The ironic word used for Communist elites signifying their well-being.

DOI: 10.1515/eas-2015-0007 C University of SS. Cyril and Methodius in Trnava. All rights reserved. 
democracy is beyond the fence [of the factory]. There, according to him, we can say whatever we want, not inside. There are factory rules. But in fact, we cannot speak even outside. One never knows who hears what we say. So you cannot really talk [on legal matters relating to minimum wage, or conditions of employment] unless you do not want to end up in problem [e.g., losing the job]." (SVKRSR3)

Participation in elections was the only widespread activity we found among our respondents. With regard to other political activities there was rarely anything mentioned. Presentism and apathy define the older generation of our respondents much more than anything else. This, again, they pass to their descendants.

"A Slovak nowadays does not deal with any 'getting along' with the past. He has a problem to live from day to day, to be able somehow, at least a bit, to progress." (SVKTTR3)

"Well, they [young man/woman] do not address the past. There is no way of doing it. The time is as it is. ... We cannot really change it [by dealing with the past]. I am trying to live in the present and look to the future." (SVKTTR3-grandson)

"For many people, the past is past. Everybody is interested today only in what is going on today. ... Whatever the Slovak Institute of Statistics says about the average salary in Slovakia, in this locality [Rimavská Sobota region] the reality is different. People run after money so that their families can survive. It's quite common here that both parents are unemployed, or that just one of them works and only for a minimal salary. Does such a man have time to visit memorials, place the garlands and kill the time? During that hour he can earn a little, or he can work on his own house ..." (SVKRSR1)

Adopting for a while the position from which many our respondents spoke can, perhaps, result in the following questions that can be read between the lines of the majority of our respondents, whether from the richer or poorest Slovak regions. If our post-socialist subjects, the people of transition and transmission, old and young, live lives often preconditioned by the economic hardships, where the role of the state in the transmission of historical discourse is doubted, challenged, and largely unheeded by the representatives of the state, where education is underpaid and therefore any attempt to revise, or otherwise debate historical discourse is limited, if memory turns to nostalgia and the serious questioning of popular interpretations of the people's pasts into a useless effort, how can we then not expect the depressing present to give rise to some kind of social unrest? Does this situation lead to any support of a new authoritarianism? Some signs of such a development can be observed especially in the poorer of the examined regions - Rimavská Sobota. The remembered past clearly serves as a focal point from which radical argumentation may arise. The success of Marián Kotleba - representative of the far right nationalist party - in 
the regional elections seems to be a direct result of the regional problems that people are unable to solve. ${ }^{18}$

"The situation is constantly degrading. The work power is degrading, the social certitudes, health system, education system .... People are literally destroyed by no guarantees ... whether they will have job, and whether, paradoxically, they will be able to say their own opinion. ... We see how the politicians change. Sometimes they are green, sometimes red, violet, on the right, on the left, in the middle ... They blur the differences [among themselves] ... They do unbelievable things and join what is not possible to join. Rightists join leftists, Christians with Communists ${ }^{19}$ and the like. It is again about the individual choices [and no common goals]. I [speaking as a politician] just want only to stick there, to have nice life, nice salary and the rest is not interesting." (SVKTTR3)

"Today we do not have to work. Who does not want, he does not. Yes, I agree with that, but then it also looks accordingly. In those times if somebody wasn't working [did not have a job] he was prosecuted and had to work in jail. The earned money he had to send to his family. And now you try to go and visit that colony where Romas are living. Some fathers are jailed for crimes and mothers with their children, what are they living from? From the state support? From what they find in dustbins? Is this about freedom? It is not. It has nothing to do with freedom at all! ...Every government only gives promises and nothing happens, so people seek something new. Yes, let us try and let's see what the new party can do. After all, what can Kotleba spoil more [when the current politicians have already spoiled everything]?" (SVKRSR1)

"Simply said, people had work, and also Romas had to work. We lived life with some quality. But mines were closed, no industry around, people started to leave, not just young ones, even we old people. We had three doctors, today there is none [in the small town our respondent came from]. We had police there and there are none today. Already four times our old house was robbed. Many Romas came to this region and bought old houses but they brought to our village [small town] only destruction. They steal, and as I say there are no police ... yes, I support Kotleba [in his anti-Roma agenda]. I know he is a donkey, yet I support him.” (SVKRSR4)

18 The generally negative attitude of Slovaks towards the current migration crisis in Europe and the measure of our help to migrants coupled with the government's stance of preference of Christian migrants, as well as, the spread of anti-migrant myths of Orientalist fashion, could also be related to the processes that lead people to support of the extremists. Further analysis of this connection is, however, out of scope of this paper.

19 This is possibly a reference to a recent political twist in Slovakia in which the leading party SMERSocial Democracy supported the pro-traditional family agenda of the Christian Democrats.

DOI: 10.1515/eas-2015-0007 C University of SS. Cyril and Methodius in Trnava. All rights reserved. 


\section{Concluding remarks}

This paper looked into what it is, in fact, that is transmitted in Slovak families as 'difficult past', and how. Among the respondents from the older generation there were certainly those who favored the popular memory of 'good times under Tiso's regime'. However, even they did not seem to prioritize uniformly this period over others and opted for a balanced view, pointing out the atrocities of the War-State. There is also observable a common platform where the notion of societal collectivity appeared quite prominently. This platform is formed by the opinions of the older people, who criticize the lack of any common societal visions/goals in the current time. They commonly explained that this state of affairs is exemplified by the fact that a wealthy economy is the only goal of the current politics, which, in turn, can be connected to the lack of financial support for the sites of memory, decline of education in history and of the general deficiency in the state support of social matters. The freedom of speech that manifests in dismissal of any single undisputed interpretation of the difficult pasts to teach, the lack of support of educational activities that could stimulate the search for yet different interpretations than those present on the public scene, the stagnation in addressing what exactly the children studying history could learn and value from the past, as well as a considerable decline in living standards in some localities when compared to living memory of the criticized Communist past -- all of this has formed a complex set of problems that culminate in nostalgia, apathy, presentism and a rising support for extreme solutions. Yet, it is rather unclear how to connect social memory, education, the lack of common goals, and the lack of future vision with the current social situation: an emerging new Slovak society that emphasizes professionalism (closely related to financial success), and the rising of extremist views.

It seems quite viable to assume that, for the society in transition, such as Slovak society perhaps still is, it would be a wide societal debate that would set a stage for contesting the experienced and imagined pasts. Perhaps the transition itself could then also transpire in clearer terms coming out of the debate. The debate is, however, still lacking the social appreciation. It may be unwise to expect that generations that were hardly taught to act individually and argumentatively will change suddenly and become active debaters, even if the political situation nowadays provides the conditions for such change. The wider societal debate is missing, perhaps, because people do not value debating. Except one, none of our respondents mentioned democratic measures - and the initiation of the societal debate, of the active and voiced participation in citizenship, is one of them - that could lead to modification of their expressed dissatisfaction and worries. The voices of various agents of change, or in political terms, of transition that we recorded are not unknown. They are present in talks, forming post-socialist folklore, but rarely heard, academically or politically. We in post-socialist societies apparently have forgotten to listen to each other. 
What then can be transmitted to younger generation other than mistrust, apathy and a call for another change, perhaps more radical than the previous one? The enchantment by the past and tradition ${ }^{20}$ (remembered, imagined or taught in school) that guarantees the bright future seems to be the outcry of a post-socialist subject, who is not heard and does not listen.

\section{References}

ASSMANN, Aleida and SHORTT, Linda (2012). 'Memory and Political Change: Introduction', In. A. Assmann and L. Shortt, eds., Memory and Political Change, pp. 114. London: Palgrave Macmillan.

BARTHES, Roland (1977). Image, music, text. New York: Hill and Wang.

BASSO, Keith, H. (1996). 'Wisdom Sits in Places. Notes on a Western Apache Landscapes.', In. Basso Keith, H. - Feld, Steven, eds., Senses of Place. Santa Fe: School of American Research Press, pp. 53-90.

BAUMAN, Zygmunt (2000). Liquid Modernity. Cambridge: Polity Press.

BERGER, Peter, L. - LUCKMANN, Thomas (1966). The Social Construction of Reality. New York: Anchor Books.

BIRTH, Kevin (2006). 'The Immanent Past: Culture and Psyche at the Juncture of Memory and 'History', Ethos 34 (2): 169-191.

BOURDIEU, Pierre (2005). „Outline of the Theory of Practice: Structures and the Habitus", In. Spiegel, Gabrielle M., ed.: Practicing History: New Directions in Historical Writing after the Linguistic Turn. New York: Routledge, pp. 179-198.

BUCHOWSKI, Michal. (2006). 'The Specter of Orientalism in Europe: From Exotic Other to Stigmatized Brother', Anthropology Quarterly, 79 (3): 463-482.

CASEY, Edward S. (1996). 'How to Get from Space to Place in a Fairly Short Stretch of Time. Phenomenological Prolegomena', In. Basso Keith, H. - Feld, Steven, eds., Senses of Place. Santa Fe: School of American Research Press, pp. 13-52.

CHAKRABARTY, Dipesh (2000). Provincializing Europe. Postcolonial Thought and Historical Difference. Princeton: Princeton University Press.

Publicist Michal Havran, on an example of the recent changes in the Slovak constitution that define marriage, or prohibit citizens who did not pass high school from running for mayor of a city, illustrates well how the laws are passed. The debate is avoided and instead the debate is ideologized, or in Havran's terms, perhaps, really magically enchanted, again. http://www.jetotak.sk/editorial/magicke-myslenie-v-ustave, accessed 6 September 2015. 
DEÁK, Dušan (2013). Addressing the 'Difficult Past': Competing Historical Narratives and the Slovak Social Memory; In.

http://www.fp7-myplace.eu/documents/Partner\%204\%20-

\%20Slovakia_deliverable_2_1_submission.pdf, accessed 6 September 2015.

DEÁK, Dušan - POPOV, Anton (2015). "Making sense of the 'difficult' past: Transmission of political heritage and memory-work among young people across Europe". The Sociological Review (Radical Futures? Youth, Politics and Activism in Contemporary Europe, eds. by Hilary Pilkington and Gary Pollock). Volume 63, Issue S2, pp. 36-52.

FOUCAULT, Michel. (1977). 'Nietzche, Genealogy, History'. In. D. Bouchard, ed., Language, Counter-Memory, Practice: Selected Essays and Interviews. Ithaca: Cornell University Press, pp. 139-164.

HAVRAN, Michal (2015). Magické myslenie vústave. In. http://www.jetotak.sk/editorial/magicke-myslenie-v-ustave, accessed 6 September 2015.

Historický časopis (2004/2, 2007/1)

HOLEC, Roman (2007). '„Krátke“ dejiny „dlhého“ storočia', Historický časopis 55 (1): 75-95.

KRISTEVA, Julia (1980). Desire in Language: A Semiotic Approach to Literature and Art. New York: Columbia University Press.

KRATOCHVÍL, Viliam. (2011) 'History teaching in the Slovak Republic', In. Erdmann, E. and Hasberg, W. (eds): Facing - Mapping - Bridging Diversity. Foundation of a European Discourse on History Education, Part 2, pp. 195-227, Erlangen: Wochenschau Verlag.

LIPTÁK, L'ubomír. (2007 [1997]). Aké dejiny potrebujeme? Forum Historiae, 1:1-7. (http://www.forumhistoriae.sk/FH1_2007/texty_1_2007/Liptak.pdf)

MAH, Alice. (2010) 'Memory, Uncertainty and Industrial Ruination: Walker Riverside, Newcastle upon Tyne', International Journal of Urban and Regional Research, 34 (2): 398-413.

MALPAS, Jeff, (1998). 'Finding Place: Spatiality, Locality, and Subjectivity'. In. Light, Andrew - Smith, M. Jonathan, eds. Philosophy and Geography. Philosophies of Place. Oxford: Rowman and Littlefield Publishers, pp. 21-43.

MICHELA, Miroslav. (2008) 'Pripomínanie a kanonizovanie minulosti. Úvaha na margo niektorých diskusií o dejinách Slovenska', Forum Historiae, 1:1-13. http://www.forumhistoriae.sk/FH1_2008/texty_1_2008/Michela.pdf 
MICHELA, Miroslav (2011). 'Strážcovia strateného času. Diskusie o dejinách a historici na Slovensku', Historický časopis 59 (4): 617-637.

NORA, Pierre (1989). 'Between Memory and History: Les Lieux de Mémoire', Representations. (Special Issue: Memory and Counter-Memory), 26 (Spring): 7-24.

OLICK. Jeffrey K. and ROBBINS, Joyce (1998). 'Social Memory Studies: From "Collective Memory" to the Historical Sociology of Mnemonic Practices', Annual Review of Sociology. 2: 105-140.

PRICA, Ines (2007). „In search of Post-socialist subject“. Croatian Journal of Ethnology \& Folklore Research / Narodna Umjetnost. Vol. 44 Issue 1, pp. 163-186. 